\title{
CAUSES AND EFFECTS OF DELAY IN CONSTRUCTION PROJECTS OF MALAKAND DIVISION, KHYBER PAKHTUNKHWA PAKISTAN
}

\author{
Bilal Karim \\ $\mathrm{PhD}$ Scholar, Department of Management Sciences, \\ Qurtuba University of Science and Information Technology, Peshawar \\ engineerbilal@hotmail.com \\ Kashif Amin \\ Associate Professor, Department of Management Sciences, \\ Qurtuba University of Science and Information Technology, Peshawar \\ kasheeamin@yahoo.com
}

\begin{abstract}
In construction projects delay is a global experience and the same issue persists in Pakistani construction industry as well. This study has its major focus on recognizing the factors of delay in government funded construction projects in Malakand division of Khyber Pakhtunkhwa Pakistan. Construction delay and its effects have been studied separately by many researchers. The current study has jointly analyzed the causes and effects of delay in government funded construction projects of Malakand division, Khyber Pakhtunkhwa Pakistan. A questionnaire assessment was executed to investigate the factors which cause delay, and their effects by considering the three main stakeholders of construction industry i.e., Contractors, Clients and Consultants. Accordingly, 50 respondents from various districts of Malakand division of Khyber Pakhtunkhwa province participated in the survey. The ten most important causes of time overrun were identified by the current study from a list of 64 causes and in the same way six effects of delay were identified. The identified 10 major causes are: $i$. Funding for project/Financial position of constructor, ii. Delayed final inspection and third-party certification iii. Weather conditions, iv. Terrorist activities in construction area, v. Delay in bills payment vi. Flood, earthquake or other natural calamities, vii. Suspension and postponement of work activities, viii. Shortage of construction materials in market, ix. Disagreements in implementation schedule of sub-contractors, $x$. Late approval and finalization of drawings. Similarly, the 6 major effects identified are: $i$. Time Overrun, ii. Disputes iii. Cost Overrun, iv. Arbitration, v. Abandonment and vi. Lawsuit. An empirical relationship between causes and effects has been developed by this study.
\end{abstract}

Keywords: Time Overrun, Construction Industry, Factors, Contractor, Consultant, Client, Construction delay.

\section{INTRODUCTION}

Construction industry has been performing a vital role in the economic development of a country and it has turned into one of the leading industries globally. The growing complexity in construction projects indicates a substantial demand from project managers for timely completion of projects within budget and other resources.

Delay in construction projects is defined as the variation between the actual contract period of a project at the time of tendering and the actual completion time of that project (Honrao \& Desai, 2015). The tendency of late accomplishment of projects and exceeding of projects from the specified finances is getting incurable worldwide and this problem is intensifying steadily (Ahmed et al., 2002). Assaf and Al-Hejji (2006) during their study in Saudi Arabia, recorded that merely thirty percent of construction projects were getting completed in their stipulated time while the rest of the projects were facing delay in completion. In their view construction delay has been a project deviation from its planned outline and is considered as a universal mess in construction projects. To a contractor, construction delay in some cases means increased overhead costs for the reason of longer work period, increased cost of material and labor due to inflation. 
A study undertaken by Chileshel and Berko (2010) in Ghana illustrated those variations in design, late payments for work done, inflation, improper scheduling and lack of appropriate knowledge regarding project were recognized as the main factors by a range of project stakeholders particularly Constructors, consultants and clients. According to Vidhyasri and Sivagamasundari (2017), creating flaw full work plans breeds unnecessary problems and uncertainties in execution of construction projects and hence results in construction delay, cost overrun, low quality infrastructure and poor performance. The factors which cause delay in construction projects must be ascertained and investigated properly. Making a proper schedule for the construction activities is an involvement practice and is based on many parameters. All these parameters are to be reviewed properly by involving expert professionals in order to make the project successful.

Frimpong et al., (2003) stressed that project implementation within stipulated budget, time and quality specified by the client are indexes of success in project management. In case of delayed project completion, the project is either accelerated or extended which ultimately leads the project to additional costs and payments. In spite of the fact that the parties agree upon the additional cost or escalation even then issues arise as to whether the construction firm is entitled for claiming the additional cost, which leads to contract interpretation.

Construction projects are composite in nature and deal with large expenses and extended time periods. Different team members perform consistent and interconnected activities in the implementation of the project. Despite that a project is carefully prepared with thorough concentration even then numerous uncertainties and unexpected situations appear. When so ever they emerge during the implementation of a construction project they lead it towards time overrun which in turn cast a very annoying effect on project execution, stakeholders and the end users as well. Before the start of the project, it is essential to know about the responsibilities of each and every person. If duties are not allocated appropriately, a possibility of discrepancy arises among the stakeholders of the project, and it can lead to lawsuits. In such circumstances managers must be acquainted with the conflict management tools in order to resolve the issues among them. Similarly, to keep the project away from delay the most significant causes and their origins must be recognized (Aleksander, 2015)

In parallel to other countries globally, Pakistani construction industry is also having a lot of issues and uncertainties, associated to time and cost overruns. Hydro power projects at Khan Khwar, Allai Khwar and Duber Khwar in Khyber Pakhtunkhwa province of Pakistan, instigated by WAPDA in 2003 and got accomplished with a time overrun of $200 \%$ on average as well as acquired 2.5 times more budget than the original estimate (Batool \& Abbas, 2017).

\section{REVIEW OF LITERATURE}

A study conducted by Assaf and Al-Hejji (2006) in Saudi Arabia recognized more than 55 factors which cause delay in building construction projects. They also gave the relative importance of each and every factor. According to the constructors interviewed, the major factors of construction delay were delayed progress of contractor, delay in preparing and approving drawings, delayed payment by client/owner and changes in design. In the view of engineers and architects the relations between subcontractors, owner's slowness in making decision proved to be the principal construction delay factors. While according to owners: shortage of labor, errors in design and improper labor skills were the major causes of delay in completion.

In research carried out in Sri Lanka by Vaardini, Ezhilmathi and Karthiyayini (2016) investigated different causes of construction delay by making use of various methods like Severity Indexing, Frequency indexing, Relative indexing methods etc. by distributing questionnaires among the respondents. They came out with a conclusion that improper scheduling and planning, lack of proper site management, alterations in materials' costs, poor financial control, inappropriate usage of resources during project execution are the main factors of construction delay.

Durdyev et al., (2012) in their descriptive survey conducted in Turkey acknowledged a range of delay factors in projects of construction. They made use of RII method for the analysis of their collected data. They analyzed the data whose results indicated that the key construction delay factors in Turkish construction projects are inappropriate planning, improper estimation of project costs, inflated costs of mandatory resources, shortage of experienced workers, high prices of land and construction materials. 
The causes of construction delay in the opinion of the 3 principal stakeholders i.e., Consultant, Client and Contractor are: delayed payment to contractors for work done, weather conditions, imprecise scheduling and project planning by contractors, too much work in hand with construction firms, lack of expert staff with construction firms.

Ismail et al., (2013) during their study in Malaysia identified the noteworthy delay causes by carrying out a questionnaire survey. They used RII method for assessment of delay causes and it was found that the 3 vital delay causes in construction industry are: financial inefficiency of the construction firms, fluctuation in material prices and contractor's substandard administration and site management.

Sweis et al. (2013) in their study about project delay, carried out in Jordan identified the factors of construction delay in governmental construction projects. They found that material price hike, increase in fuel prices, changes in design, deficiency of expertise, lack of knowledge regarding local set of laws, shortage of equipment's and weather conditions are the principal delay causes in public sector construction projects of Jordan.

After analysis of many documents and reports of a number of projects, Al-Hazim and Salem (2015) came to know that the major construction delay factors are: Variation orders, Terrain and weather conditions and unavailability of labor force.

During a study of Indian construction projects, Shanmugapriya and Subramanian (2013) examined the vital construction delay factors by going through a questionnaire assessment. The analysis of the data collected from the 3 core agencies of construction industry namely contractors, clients and consultants through questionnaire was carried out by making use of the method of RII. It was found that the major construction delay factors in Indian construction projects were adjustment of contracts, market rate of material and high quality of work constraint.

Construction projects face delay because of the client's delayed provision of some of the material to the constructor and client's delayed payments of running bills. Some other related problems together with the above-mentioned problem like getting belated clearances and approved drawings/designs from clients and consultants make it much difficult to complete the project in time. An additional challenge faced by the construction industry has been the resources' low productivity particularly productivity of equipment's (Mulla \& Waghmare, 2015).

After the review of literature and analysis of questionnaire Kamble and Dhawade (2016) recognized the principal construction delay causes in Indian construction projects. They pointed it out that local political interference, Ill project scheduling and planning of activities, belated payments by client to constructor, insufficient funds' allotment, material prices escalation were the key factors of construction delay in Indian construction industry. They used Relative Importance Index for ranking and analyzing these factors.

Koushki et al., (2005) executed a research study in the State of Kuwait for delay in private residential construction projects. They recorded the 3 major factors of construction delay as financial constraints of owner/client, change in orders and lack of expertise with owner in the business of construction. They recommended that these factors can be minimized by ensuring the availability of proper funding source, adequate time allocation and funds at the planning stage and hiring a reliable and experienced construction firm as well as consultant to execute the project successfully.

Efficient communication among the stakeholders of a project is vital for its success. Consistent with Sambasivan and Soon's (2007) findings, oil and gas construction projects of Oman deteriorated due to poor communication among stakeholders of the project. The problem of communication gap always results in rework and thus delay in completion of a project occurs. For that reason, to lessen the risk of delay, it is crucial to ascertain a proper channel of communication for all the stakeholders of a project. Also, informal channels of communication be ascertained as they facilitate convenient flow of information among stakeholders of the project in a shorter time span (AlRawas \& Easterbrook, 1996; Bassi et al., 2012).

A research study carried out by Ramanathan et al. (2012) acknowledged that rising demand of resources like construction material, labor force and construction equipment's can cause scarcity of these resources and consequently it will slow down the execution of projects. It was also concluded that mismanagement on the part of owner, consultant and contractor will surely direct the project to delay. They derived from reviewing 7 case studies regarding delay in the execution of construction projects that the factors causing delay in project completion were lack of standard material and proper 
equipment's in the local market, delayed delivery of material, absence of schedule for delivery of material by the contractor, late approval of drawings by consultant, unpredictable weather conditions, delayed dealing with property owners at construction site, fluctuation in prices of raw material and amendments because of below standard works. They also recommended that for elimination of the negative impact these issues must be taken care of at pre-design stage.

In their study conducted in Jordan for the purpose of finding out the factors causing delay in construction projects, Sweis et. al (2008) pointed out that financial problems of the construction firms, change orders from client and improper project scheduling by constructors prove to be the key factors of delay in residential construction projects. They also argued that the main causes of delay are connected with the environment of the system particularly that of the construction company and the labor, whereas the external causes cast a very minor effect on completion of project.

Sambasivan and Soon (2007) carried out a study regarding the causes of delay in construction industry of Malaysia. They conducted a survey where 150 participants took part. Their study recognized ten key factors which cause delay in construction projects from a list of twenty-eight various factors. The 10 key factors identified are: insufficient experience of contractor, poor planning by the contractor, contractor's poor management of site, improper payment to contractors for work done by client, subcontractors' issues, material shortage, shortage of labor, unavailability and failure of equipment's, communication gap among stakeholders and blunders during construction.

\section{METHODOLOGY}

The assessment of the perceptions of contractors, clients and consultant was conducted by developing a self-administered questionnaire. The questionnaire was having 3 portions. Portion 1 st was regarding the information about the respondents. The focus of 2 nd portion of the questionnaire was on the factors causing time overrun in government funded construction projects in Malakand division of Khyber Pakhtunkhwa Pakistan. The participants were asked to respond in Likert scale of 1 to 5 to sixty-four well-recognized construction delay factors identified from the literature of many studies. The following 7 categories accommodated all the construction delay factors.

1. Factors related to Client: Belated payment to contractor for work done, owner's unnecessary hindrance, impractical duration of contract by client, owner's slow decision making.

2. Factors related to Contractor: Subcontractors' delayed initiation of work, site administration, inappropriate methods of construction, inappropriate scheduling, mistakes at some stages in construction and insufficient experience of contractor.

3. Factors related to Consultant: Drawings' preparation and approval, Contract management, Assuring quality, delayed inspections and approval of tests.

4. Factors related to Material: Shortage of material and below quality material in market.

5. Factors related to labor and equipment's: Shortage of experienced labor, Low productivity of labor and unavailability and failure of equipment's.

6. Factors related to External conditions: unpredictable weather condition, Administrative or governmental changes, disputes with neighbors and terrorism activities.

7. Factors related to Project: unavailability of material at site, difficulty in accessibility of construction site, difficulties in contract relationships, key disputes among stakeholders and communication gap among parties.

During the questionnaire survey the participants were requested to emphasize their suggestions for improving the performance of Pakistani construction industry, Khyber Pakhtunkhwa in particular by responding to the open-ended queries in the questionnaire.

Third portion of the questionnaire was focusing on the effects of delay in government funded construction projects of Khyber Pakhtunkhwa Pakistan. The already recognized 6 effects of delay in construction projects from the review of literature were: time overrun, cost overrun, arbitration, dispute, litigation, and project abandonment. Parallel to 2 nd portion the participants were requested to show up their commendations for minimizing the effects of delay by responding to an open-ended query in the questionnaire.

Likert scale from 1 (very low) to 5 (very high) was used to know about the significance of causes and effects of delay in construction projects. Prior to questionnaire distribution, a pilot study was carried out by investigating 5 clients, 5 consultants, and 5 number of contractors. The main reason of this practice was to make sure the integrity of the questionnaire and to verify the 
completeness of the questionnaire in mentioning the causes of delay applicable for Khyber Pakhtunkhwa Pakistan. All the participants approved that the questionnaire was satisfactory for capturing the causes and effects of delay. Therefore, no changes were made to the identified causes and delays from the review of various studies related to construction delay in different countries.

The technique used by this study for the purpose of collection of data was simple random form of the probability sampling. Out of the total 482 construction companies (contractors), 50 companies were selected randomly from the PEC list of companies working on government funded construction projects in Malakand division of Khyber Pakhtunkhwa province of Pakistan for the purpose of collection of data. Sample size for this study has been determined by making use of krejcie and Morgan Formula. Questionnaires were distributed in person and through friends working in the construction industry of Malakand division, Khyber Pakhtunkhwa Pakistan. A total number of fifty sets of questionnaires were distributed among potential respondents within the construction industry of Khyber Pakhtunkhwa. All the 50 questionnaires, means 100 percent were returned filled.

\section{RII Calculation}

The method of finding the relative importance index of each and every factor has been used by a number of researchers like Sambasivan and Soon (2007), Kometa et al., (1994) etc. In the current study the same RII method was applied to find out the relative importance of each and every cause of delay in government funded construction projects of Malakand division, Khyber Pakhtunkhwa Pakistan. Likert scale from 1 (very low) to 5 (very high) was used to know about the significance of causes and effects of construction delay and changed to RII for each factor as below.

Relative Importance Index, RII $=\sum \mathrm{W} / \mathrm{A} * \mathrm{~N}$.

Where "W" indicates the weightage specified for each cause by the respondents, "A" shows the maximum weightage i.e., 5 in case of our study and "N" denotes the overall number of participants.

Relative Importance Index ranged between zero and one. The higher value of RII of a factor means higher importance of that factor for causing time overrun. The purpose of using "RII" was for the ranking of various factors which cause time overrun which enabled us to compare the relative importance of the factors as in the view of the most important 3 pillars of construction industry i.e consultants, clients, and contractors. The relative importance index of each cause as observed by all the participants was used to evaluate the overall rankings for presenting an overall picture of factors causing delay in government funded construction projects of Malakand division, Khyber Pakhtunkhwa Pakistan. Same was the case with the effects of delay. RII for each effect was calculated and ranked accordingly which enabled us to mark the most important and highly ranked effect of delay in construction industry of Malakand division, Khyber Pakhtunkhwa Pakistan.

The method of Relative Importance Index has been used by many researchers for their studies. Table .1 shows the details of the authors who used the same method in their studies.

Table No. 1 


\begin{tabular}{|l|l|l|l|}
\hline S.No & Authors & Techniques & Country of study \\
\hline 1 & Odeh and Battaineh (2002) & Importance Index (II) & Jordan \\
\hline 2 & Assaf and Al-hejji (2006) & Relative importance index (RII) & Saudi Arabia \\
\hline 3 & Aibinu and Odeyinka (2006) & Relative importance index (RII) & Nigeria \\
\hline 5 & Sambasivan and Soon (2007) & Relative importance index (RII) & Malaysia \\
\hline 6 & Enshassi et al. (2009) & Relative importance index (RII) & Gaza Strip (Palestine) \\
\hline 7 & Fugar and Agyakwah-baah (2010) & Relative importance index (RII) & Ghana \\
\hline 8 & Doloi et al. (2012) & Relative importance index (RII) & India \\
\hline 9 & Kazaz et al. (2012) & Mean Importance Rating (MIR) & Turkey \\
\hline 10 & Fallahnejad (2013) & Relative importance index (RII) & Iran \\
\hline 11 & Akogbe et al. (2013) & Relative importance index (RII) & Benin \\
\hline 12 & Aarzouk and El-Rasas (2014) & Relative importance index (RII) & Egypt \\
\hline 13 & Durdyev et al. (2017) & Relative importance index (RII) & Egypt \\
\hline 14 & Sambasivan et al. (2017) & Relative importance index (RII) & Cambodia \\
\hline 15 & Al-Emad et al. (2017) & Avelative importance index (RII) & Tanzania \\
\hline 16 & Mpofu et al. (2017) & Relative importance index (RII) & UAE (AI) Makkah \\
\hline 17 & Bagaya and Song (2016) & Importance index (II) & Burkina Faso \\
\hline 18 & Chen et al. (2017) & Mean importance rating (MIR) & China \\
\hline 19 & Maqsoom et al. (2018) & Mean importance rating (MIR) & Pakistan \\
\hline R & S A A Daudi) & \\
\hline
\end{tabular}

\section{RESULTS AND DISCUSSION}

Table below contains the characteristics of the participants on the basis of their demography. In accordance with the gathered data, 14 respondents were in the age group of 31-40, 19 were in the age group of 41-50 while rest were in the age group above 51 as shown in table below. In a similar way job designation of the respondents showed that 5 of the respondents were working as Chief Engineers, 10 were working as CEOs, 1 was Engineer, 2 were Executive officers, 1 was General Manager, 11 were MDs, 8 were senior engineers, 9 were site engineers, 2 were sub divisional officers and 1 was technical head of their respective organizations.

Table No. 2.

\begin{tabular}{|c|c|c|}
\hline Demographic Characteristics & Frequency & Percentage \\
\hline \multicolumn{3}{|l|}{ Age } \\
\hline $31-40$ & 14 & 28 \\
\hline $41-50$ & 19 & 38 \\
\hline Above 51 & 17 & 34 \\
\hline \multicolumn{3}{|l|}{ Sex } \\
\hline Male & 50 & 100 \\
\hline \multicolumn{3}{|c|}{ Job Designation of the Respondent } \\
\hline Chief Engineer & 5 & 10 \\
\hline Chief Executive Officer (CEO) & 10 & 20 \\
\hline Engineer & 1 & 2 \\
\hline Executive Officer & 2 & 4 \\
\hline General Manager & 1 & 2 \\
\hline Managing Director & 11 & 22 \\
\hline Senior Engineer & 8 & 16 \\
\hline Site Engineer & 9 & 18 \\
\hline Sub Divisional Officer & 2 & 4 \\
\hline Technical Head & 1 & 2 \\
\hline \multicolumn{3}{|c|}{ Type of Organization the respondent is working in } \\
\hline Client & 2 & 4 \\
\hline Contractor & 46 & 92 \\
\hline Consultant & 2 & 4 \\
\hline
\end{tabular}

Table No. 3 Categorization Of Experience of Respondents 


\begin{tabular}{|l|l|c|c|} 
S.No & Experience Category & No. of Respondents & Percentage \\
\hline 1 & 01 to 12 years & 5 & 10 \\
\hline 2 & 13 to 18 years & 11 & 22 \\
\hline 3 & 19 to 25 years & 23 & 46 \\
\hline 4 & 26 to 30 years & 8 & 16 \\
\hline 5 & above 30 years & 3 & 6 \\
\hline
\end{tabular}

The above table indicates that 5 of the respondents belonged to the experience category of 1-12 years, 11 belonged to 13-18 years, 23 belonged to 19-25 years, 8 belonged to 26-30 years while 3 of them belonged to the experience category of above 30 years' experience.

\section{Causes Of Delay}

The second portion of the questionnaire collected the primary data whose analysis was carried out from the viewpoint of contractors, clients and consultants. For the purpose of overall analysis, each individual factor's relative importance index, as viewed by all the participants, was calculated. For identification of the most important factors causing delay in construction projects the RII was calculated for each and every factor and all the factors were ranked on the basis of their values. This ranking enabled us to recognize the most significant causes of time delay in the construction projects of Khyber Pakhtunkhwa Pakistan.

On the basis of this ranking the most significant five factors causing delay in construction projects related to the three important pillars i.e Client, Contractor and Consultant are as below;

Table No. 4

\begin{tabular}{|c|c|c|c|}
\hline S.No & Factors & $\begin{array}{c}\text { Relative Importance } \\
\text { Index }\end{array}$ & Rank \\
\hline \multicolumn{4}{|c|}{ Client related factors } \\
\hline 1 & Delayed payment of bills & 0.99 & 1 \\
\hline 2 & Suspension and postponement of work activities & 0.99 & 2 \\
\hline 3 & Belated site delivery to contractor & 0.98 & 3 \\
\hline 4 & Belated approval and finalization of drawings & 0.98 & 4 \\
\hline 5 & Slowness in making decision & 0.98 & 5 \\
\hline \multicolumn{4}{|c|}{ Contractor's related factors } \\
\hline 1 & Belated approval and finalization of drawings & 0.992 & 1 \\
\hline 2 & Laziness in making decisions & 0.984 & 2 \\
\hline 3 & Belated evaluation \& approval of designs & 0.98 & 3 \\
\hline 4 & Variations in specifications & 0.976 & 4 \\
\hline 5 & Delayed supervision of site & 0.964 & 5 \\
\hline \multicolumn{4}{|c|}{ Consultant related factors } \\
\hline 1 & Financial capability of contractor (funding for project) & 0.996 & 1 \\
\hline 2 & Disputes in sub contractors' implementation schedule & 0.992 & 2 \\
\hline 3 & Frequently changing sub contractors/suppliers & 0.984 & 3 \\
\hline 4 & Delayed delivery of material at the construction site & 0.984 & 4 \\
\hline 5 & Belated work of sub contractor & 0.98 & 5 \\
\hline
\end{tabular}

The vital 10 construction delay causes in construction projects of Khyber Pakhtunkhwa as identified through the current study are; Constructor's Financial capacity (0.996), Weather effect (0.994), Environmental restrictions(0.994), Slowness in permission (0.993), 3rd party's delayed inspection and certification (0.993), War against terror, protests, strikes etc., (0.992), Terrorist activities in the area of the construction site (0.992), Earthquake, Flood or any other natural disaster(0.991), belated bill payments (0.990), Suspension and postponement of work activities(0.988). 


\section{Karim \& Amin}

All the factors identified in this study have been ranked according to their RII values. The ranking of all those construction delay factors in construction industry of Khyber Pakhtunkhwa Pakistan has been shown in table 5 . 
Table No. 6

\begin{tabular}{|c|c|c|c|c|c|}
\hline S.No & Factors & Category & $\begin{array}{l}\text { Total } \\
\text { Value }\end{array}$ & RII & Rank \\
\hline 1 & Financial capability of contractor (funding for project) & Contractor & 249 & 0.996 & 1 \\
\hline 2 & Weather effect (Snow fall, hot, rain, etc.) & External Conditions & 249 & 0.996 & 2 \\
\hline 3 & Environmental restrictions & External Conditions & 249 & 0.996 & 3 \\
\hline 4 & Slowness in permission by government/municipality & External Conditions & 249 & 0.996 & 4 \\
\hline 5 & War against terror, protests, strikes etc. & External Conditions & 249 & 0.996 & 5 \\
\hline 6 & a third & External Conditions & 249 & 0.996 & 6 \\
\hline 7 & Terrorist activities in the area of the construction site & External Conditions & 249 & 0.996 & 7 \\
\hline 8 & Earthquake, Flood or any other natural disaster & External Conditions & 249 & 0.996 & 8 \\
\hline 9 & Delayed payment of bills & Client & 248 & 0.992 & 9 \\
\hline 10 & Suspension and postponement of work activities & Client & 248 & 0.992 & 10 \\
\hline 11 & Belated approval and finalization of drawings & Consultant & 248 & 0.992 & 11 \\
\hline 12 & Disputes in sub contractors' implementation schedule & Contractor & 248 & 0.992 & 12 \\
\hline 13 & Shortage of construction materials in market & Material & 248 & 0.992 & 13 \\
\hline 14 & Shortage of labours & Labor & 248 & 0.992 & 14 \\
\hline 15 & Low productivity level of labours & Labor & 248 & 0.992 & 15 \\
\hline 16 & Traffic control and restriction at job site & Construction Site & 247 & 0.988 & 16 \\
\hline 17 & Belated site delivery to contractor & Client & 246 & 0.984 & 17 \\
\hline 18 & Belated approval and finalization of drawings & Client & 246 & 0.984 & 18 \\
\hline 19 & Laziness in making decisions & Consultant & 246 & 0.984 & 19 \\
\hline 20 & Frequently changing sub contractors/suppliers & Contractor & 246 & 0.984 & 20 \\
\hline 21 & Delayed delivery of material at the construction site & Contractor & 246 & 0.984 & 21 \\
\hline 22 & construction & Material & 246 & 0.984 & 22 \\
\hline 23 & Equipment availability and failure & Labor & 246 & 0.984 & 23 \\
\hline 24 & Unavailability of utilities in site & Construction Site & 246 & 0.984 & 24 \\
\hline 25 & Belated evaluation \& approval of designs & Consultant & 245 & 0.98 & 25 \\
\hline 26 & Belated work of sub contractor & Contractor & 245 & 0.98 & 26 \\
\hline 27 & table, etc.) & Construction Site & 245 & 0.98 & 27 \\
\hline 28 & Slowness in making decision & Client & 244 & 0.976 & 28 \\
\hline 29 & Variations in specifications & Consultant & 244 & 0.976 & 29 \\
\hline 30 & Delay in material delivery & Material & 244 & 0.976 & 30 \\
\hline 31 & Fluctuations in cost/ currency & External Conditions & 244 & 0.976 & 31 \\
\hline 32 & Ambiguity about material & Client & 243 & 0.972 & 32 \\
\hline 33 & Changes in government regulations and laws & External Conditions & 243 & 0.972 & 33 \\
\hline 34 & Delayed supervision of site & Consultant & 241 & 0.964 & 34 \\
\hline 35 & Use of inappropriate methods of construction & Contractor & 240 & 0.96 & 35 \\
\hline 36 & Ineffective planning and scheduling of project & Contractor & 240 & 0.96 & 36 \\
\hline 37 & Delay in site mobilization & Contractor & 240 & 0.96 & 37 \\
\hline 38 & Details lacking in conceptual drawings & Consultant & 239 & 0.956 & 38 \\
\hline 39 & Unqualified Engineers and other staff & Contractor & 239 & 0.956 & 39 \\
\hline 40 & Human resource issues with contractor & Contractor & 239 & 0.956 & 40 \\
\hline 41 & Unqualified workforce & Labor & 239 & 0.956 & 41 \\
\hline 42 & Slowness in giving instructions & Consultant & 238 & 0.952 & 42 \\
\hline 43 & Variations in original drawing & Client & 234 & 0.936 & 43 \\
\hline 44 & Unrealistic completion time concerns & Client & 234 & 0.936 & 44 \\
\hline 45 & the site & Construction Site & 233 & 0.932 & 45 \\
\hline 46 & Lack of communication between the parties & External Conditions & 233 & 0.932 & 46 \\
\hline 47 & Weak supervision of construction site & Contractor & 232 & 0.928 & 47 \\
\hline 48 & Accident during construction & Construction Site & 232 & 0.928 & 48 \\
\hline 49 & Corruption & Client & 231 & 0.924 & 49 \\
\hline 50 & Communication gap with the contractor & Consultant & 231 & 0.924 & 50 \\
\hline 51 & Unskilled consultancy staff at site & Consultant & 231 & 0.924 & 51 \\
\hline 52 & Unavailability of consultant's staff at the site & Consultant & 231 & 0.924 & 52 \\
\hline 53 & Problem with neighbors & Construction Site & 229 & 0.916 & 53 \\
\hline 54 & Rigidity of Client's representative & Client & 227 & 0.908 & 54 \\
\hline 55 & Disputes of contractor with client and consultant & Contractor & 226 & 0.904 & 55 \\
\hline 56 & Communication gap with contractor & Client & 221 & 0.884 & 56 \\
\hline 57 & Consultant's rigidity & Consultant & 220 & 0.88 & 57 \\
\hline 58 & Clients interruption & Client & 218 & 0.872 & 58 \\
\hline 59 & Conflicts among labor force & Labor & 217 & 0.868 & 59 \\
\hline 60 & Injury of labors during work & Labor & 217 & 0.868 & 60 \\
\hline 61 & Communication gap with other parties & Contractor & 216 & 0.864 & 61 \\
\hline 62 & Rigidity of contractors staff with labor force & Labor & 216 & 0.864 & 62 \\
\hline 63 & Wages problems & Labor & 211 & 0.844 & 63 \\
\hline 64 & Labor's nationality & Labor & 209 & 0.836 & 64 \\
\hline
\end{tabular}


Table No. 7 Categories Wise Ranking

\begin{tabular}{c|l|c|c|} 
S.No & Category & RII & Rank \\
\hline 1 & Factors related to External conditions & 0.99 & 1 \\
\hline 2 & Factors related to Material & 0.98 & 2 \\
\hline 3 & Factors related to Contractor & 0.96 & 3 \\
\hline 4 & Factors related to Construction site & 0.95 & 4 \\
\hline 5 & Factors related to Consultant & 0.95 & 5 \\
\hline 6 & Factors related to Client & 0.95 & 6 \\
\hline 7 & Factors related to Labor & 0.91 & 7 \\
\hline
\end{tabular}

Table No. 8 Overall Ranking of Factors

\begin{tabular}{r|l|l|c|c|c|c|} 
S.No & Factors & Category & $\begin{array}{c}\text { RII of } \\
\text { impact }\end{array}$ & $\begin{array}{c}\text { RII of } \\
\text { Frequency }\end{array}$ & $\begin{array}{c}\text { Over } \\
\text { All RII }\end{array}$ & Rank \\
\hline 1 & Financial capability of contractor (funding for project) & Contractor & 0.996 & 0.928 & 0.92 & 1 \\
\hline 2 & Weather effect (Snow fall, hot, rain, etc.) & External Factors & 0.996 & 0.924 & 0.92 & 2 \\
\hline 3 & Delay in performing final inspection by third party & External Factors & 0.996 & 0.92 & 0.92 & 3 \\
\hline 4 & Terrorist activities in the area of the construction site & External Factors & 0.996 & 0.908 & 0.9 & 4 \\
\hline 5 & Earthquake, Flood or any other natural disaster & External Factors & 0.996 & 0.896 & 0.89 & 5 \\
\hline 6 & Delayed payment of bills & Client & 0.992 & 0.864 & 0.86 & 6 \\
\hline 7 & Suspension and postponement of work activities & Client & 0.992 & 0.856 & 0.85 & 7 \\
\hline 8 & Belated approval and finalization of drawings & Consultant & 0.992 & 0.852 & 0.85 & 8 \\
\hline 9 & Disputes in sub contractors' implementation schedule & Contractor & 0.992 & 0.844 & 0.84 & 9 \\
\hline 10 & Shortage of construction materials in market & Material & 0.992 & 0.84 & 0.83 & 10 \\
\hline
\end{tabular}

Table No. 9 Ranking Of Seven Districts of Malakand Division on the Basis of RII

\begin{tabular}{l|l|c|c|}
\hline S.No & District & RII & Rank \\
\hline 1 & Swat & 62.51 & 1 \\
\hline 2 & Shangla & 62.03 & 2 \\
\hline 3 & Dir Lower & 61.23 & 3 \\
\hline 4 & Dir Upper & 60.66 & 4 \\
\hline 5 & Buner & 60.54 & 5 \\
\hline 6 & Chitral & 60.46 & 6 \\
\hline 7 & Malakand & 59.6 & 7 \\
\hline
\end{tabular}

The 10 principal factors of construction delay recognized in this study from the questionnaire based on how frequently they occur, and the magnitude of their impact are illustrated as follow. The relative importance index (RII) of Financial capability of contractor is 0.92 , RII of Weather effect i.e., Hot, Snow fall, rain and Delayed certification and inspection etc is 0.92, RII for activities related to terrorism in construction area is 0.90 , RII value for natural disaster like Flooding and earthquake etc is 0.89 , belated bill payment to contractor for work done has RII value equal to 0.86 , RII value of Suspension and postponement of work activities is 0.85 , In the same way the RII for delayed approving 
and drawing finalization is 0.85 , Value of RII for Disputes in implementation schedule of sub contractors is 0.84 while the value of Relative importance index for scarcity of material is 0.83 .

Table No. 10 Ranking Of Effects Of Construction Delay

\begin{tabular}{|l|c|c|c|c|c|c|c|}
\hline Effects & \multicolumn{5}{|c|}{ Percentage of Participants Score } & RII & Rank \\
\hline Time Overrun & 0 & 0.7 & 19.6 & 57 & 22.7 & 0.801 & 1 \\
\hline Cost Overrun & 0.8 & 2.6 & 29.1 & 37.5 & 30 & 0.787 & 2 \\
\hline Disputes & 0.6 & 14.8 & 40.3 & 39 & 5.3 & 0.665 & 3 \\
\hline Arbitration & 1.98 & 22.11 & 45 & 25 & 5.3 & 0.619 & 4 \\
\hline Litigation & 4.7 & 21.3 & 48.7 & 22.7 & 2.7 & 0.595 & 5 \\
\hline Abandonment & 6.7 & 36 & 29.3 & 21.3 & 6.7 & 0.5716 & 6 \\
\hline
\end{tabular}

The above table shows that the most important effect on the basis of RII is Time overrun having a value of 0.801 . It means the causes of delay highly affect the project completion in the form of time overrun. Cost overrun has RII value of 0.787 which means it is also a big effect of the causes of delay. Disputes with RII value of 0.665 is ranked 3rd, Arbitration with value of 0.619 is ranked 4th, Litigation with value of 0.595 is ranked 5th while abandonment with a value of 0.571 has been ranked 6th by this study.

\section{CONCLUSION}

The current research study was intended to judge the viewpoint of consultants, contractors and clients about the most important factors which cause delay in construction projects of Malakand division of Khyber Pakhtunkhwa Pakistan. For that purpose, a questionnaire survey was conducted in construction industry of Malakand division which clearly identified the main factors causing delay in construction projects. These factors were further ranked on the basis of RII with the aim to know the major factor causing construction delay. The results obtained from the analysis showed that financial capability of contractor, belated final assessment by a third Party, weather effect i.e., hot, snow fall, rain, etc., delayed payment of bills to contractor for work done, terrorism activities in the area of the construction, earthquake, flood or any other natural disaster, suspension and postponement of work activities, disputes in sub contractors' implementation schedule, belated approval and finalization of drawings, shortage of construction materials in market are the most important factors of delay in construction projects in Malakand division of Khyber Pakhtunkhwa Pakistan.

Similarly, it was also recognized by the current study that external conditions, material, contractor, construction site, consultant, client, labor are the major categories causing delay in construction projects of Malakand division. The current study identified that the most effected district of Malakand division because of these causes is district Swat, followed by district Shangla and Dir Lower on the basis of relative importance index of these causes.

Though the current study is confined to the construction projects of Malakand division of Khyber Pakhtunkhwa, the stakeholders of the construction industry in other divisions and provinces of the country can also take help from its findings in understanding the principal causes of delay in construction projects. In addition, the majority of the identified factors in this study confirms those identified in previously conducted studies specifically in developing countries of Asia and Africa.

To avoid schedule delays in construction projects there are no simple elucidation to the challenges in construction projects of Malakand division. However, some systematic steps that we can take to lessen these causes are recommended as follow;

1. It is direly needed to improve the management skills of the staff related to construction industry. The construction staff/workers should be trained with the required techniques and skills including planning, costing, time control, risk analysis etc. 
2. Project partners must review all the clauses of payment in the contract. A translucent and precise procedure and timeline must be clearly specified in the contract and payment against work done must be ensured timely. Moreover, the schedule of payment must be prepared at the planning stage in order to ensure that construction companies and consultants are paid in a regular way.

3. A realistic and easy to achieve duration for the completion of work should be defined by the client in the contract in order to avoid extension of time and rework.

4. Construction companies should regularly monitor the quality of their construction works for the purpose to avoid mistakes which always lead to rework and hence extension in project time.

5. Contractors should not try to engage lowest priced sub-contractors but during selection of sub-contractors the expertise and technical abilities of their staff should be considered.

6. Clients should straightforwardly interfere in case there is a dispute between contractors and subcontractors in order to minimize the harmful impact on implementation of project.

7. Construction firms should take an early action to attain approvals of various governmental departments to avoid possible consequences on schedule of project.

8. The current study has worked on the factors causing delay and their impacts on construction projects. A research study regarding the effects of construction delays and how to minimize them can also be carried out.

\section{REFERENCES}

Ahmed, S. M., Azhar, S., Castillo, M., \& Kappagantula, P. (2002). Construction delays in Florida: An empirical study. Final report. Department of Community Affairs, Florida, US.

Al-Hazim, N., \& Salem, Z. A. (2015). Delay and cost overrun in road construction projects in Jordan. International Journal of Engineering \& Technology, 4(2), 288.

Al-Rawas, A., \& Easterbrook, S. M. (1996). Communication problems in requirements engineering: a field study (pp. 47-60). National Aeronautics and Space Administration.

Assaf, S. A., \& Al-Hejji, S. (2006). Causes of delay in large construction projects. International journal of project management, 24(4), 349-357.

Bassi, A., Howard, R., Geneletti, D., \& Ferrari, S. (2012). UK and Italian EIA systems: A comparative study on management practice and performance in the construction industry. Environmental Impact Assessment Review, 34, 1-11.

Batool, A., \& Abbas, F. (2017). Reasons for delay in selected hydro-power projects in Khyber Pakhtunkhwa (KPK), Pakistan. Renewable and Sustainable Energy Reviews, 73, 196-204.

Chileshel, N., \& Berko, P. D. (2010, July). Causes of project cost overruns within. In Proceedings 51" Built Environment Conference (Vol. 18, p. 20).

Durdyev, S., Ismail, S., \& Bakar, N. A. (2012). Factors causing cost overruns in construction of residential projects: case study of Turkey. International Journal of Science and Management, 1(1), 3-12.

Frimpong, Y., \& Oluwoye, J. (2003). Significant factors causing delay and cost overruns in construction of groundwater projects in Ghana. Journal of Construction Research, 4(02), 175-187.

Honrao, Y., \& Desai, D. (2015). Study of delay in execution of infrastructure projects-highway construction. International Journal of Scientific and Research Publications, 5(6), 1-8.

Kamble, Y. G., \& Dhawade, S. M. (2016) Impact of Equipment Downtime on Construction Projects.

Kometa, S. T., Olomolaiye, P. O., \& Harris, F. C. (1994). Attributes of UK construction clients influencing project consultants' performance. Construction Management and economics, 12(5), 433-443.

Koushki, P. A., Al-Rashid, K., \& Kartam, N. (2005). Delays and cost increases in the construction of private residential projects in Kuwait. Construction Management and Economics, 23(3), 285-294.

Maqsoom, A., Khan, M. U., Khan, M. T., Khan, S., \& Ullah, F. (2018). Factors influencing the construction time and cost overrun in projects: empirical evidence from Pakistani construction industry. In Proceedings of the 21st International Symposium on 
Advancement of Construction Management and Real Estate (pp. 769-778). Springer, Singapore.

Mulla, S. S., \& Waghmare, A. P. (2015). Influencing factors caused for time \& cost overruns in construction projects in Pune-India \& their remedies. Int. J. Innovative Sci. Eng.

Technol, 2(10), 622633.

Odeh, A. M., \& Battaineh, H. T. (2002). Causes of construction delay: traditional contracts. International journal of project management, 20(1), 67-73.

Patil, A. P. (2017). Analysis of Cost over run in construction Projects. International Research Journal of Engineering and Technology (IRJET), 4(11), 1234-1237.

Rahman, I. A., Memon, A. H., Karim, A. T. A., \& Tarmizi, A. (2013). Significant factors causing cost overruns in large construction projects in Malaysia. Journal of Applied Sciences, 13(2), 286-293.

Ramanathan, C., Potty, N. S., \& Idrus, A. B. (2012). Analysis of time and cost overrun in Malaysian construction. In Advanced Materials Research (Vol. 452, pp. 1002-1008). Trans Tech Publications Ltd.

Sambasivan, M., \& Soon, Y. W. (2007). Causes and effects of delays in Malaysian construction industry. International Journal of project management, 25(5), 517-526.

Shanmugapriya, S., \& Subramanian, K. (2013). Investigation of significant factors influencing time and cost overruns in Indian construction projects. International Journal of Emerging Technology and Advanced Engineering, 3(10), 734-740.

Srdić, A., \& Šelih, J. (2015). Delays in construction projects: causes and mitigation. Organization, technology \& management in construction: an international journal, 7(3), 1383-1389.

Sweis, G. J. (2013). Factors affecting time overruns in public construction projects: The case of Jordan. International journal of business and management, 8(23), 120.

Sweis, G. J., Sweis, R., Hammad, A. A., \& Shboul, A. (2008). Delays in construction projects: The case of Jordan. International Journal of project management, 26(6), 665-674.

Vaardini, S., Karthiyayini, S., \& Ezhilmathi, P. (2016). Study on cost overruns in construction projects: a review. International Journal of Applied Engineering Research, 11(3), 356-363.

Vidhyasri, R., \& Sivagamasundari, R. (2017). A review on factors influencing construction project scheduling. International Journal of Civil Engineering and Technology, 8(3), 146-157. 